Received $13^{\text {th }}$ October 2017, Accepted $27^{\text {th }}$ November 2017

Link to DOI:

10.25220/WNJ/V01.i2.0003

Journal Website: www.worldnutrijournal.org

\section{IGF-1 Levels Among Adolescent Girls Living in Jakarta and Its Relation to Nutritional Status}

Maretha Primariayu, ${ }^{1}$ Ririn Hariani, ${ }^{2}$ Saptawati Bardosono, ${ }^{1}$ Noorwati Sutandyo ${ }^{2}$

\author{
1. Department of Nutrition Faculty of Medicine Universitas Indonesia-Cipto Mangungkusumo \\ General Hospital \\ 2. Dharmais Cancer Hospital, Jakarta, Indonesia
}

\begin{abstract}
Introduction: Insulin-like growth factor (IGF)-1 is one of the hormones that plays a role in the growth of adolescent girls. Its level will rise at puberty and begin to decline at the end of puberty. High IGF-1 levels in adult is associated with the incidence of breast cancer. This study aims to know the level of IGF-1 and investigates its relationship with dietary intake, nutritional status, and physical activity of adolescent girls aged 13-15 in Jakarta.

Methods: This cross-sectional study used secondary data from a previous study (titled "Determinant Factor Levels of Estradiol, IGF-1, and Early Menarche in Adolescent Girls Aged 13-15 in Jakarta: Nutritional Epidemiology Study Related to Breast Cancer Risk Factors") and primary data from stored blood serum to measure IGF-1 levels by colorimetric method. The secondary data such as dietary intake, anthropometric data, and physical activities were obtained from 178 subjects with a total population sampling method.

Results: There was a positive correlation between IGF-1 levels and carbohydrate intake $(p=0.041$, $r=0.153)$ and a negative correlation between IGF-1 levels and fat intake $(p=0.042, r=-0.152)$. No correlation between IGF-1 and body mass index was found, but there was a tendency that IGF-1 values would increase in overweight and decrease in obesity. IGF-1 levels have nonlinear pattern by carbohydrates intake, fat intake and nutritional status.

Conclusion: The adolescent girls should maintain their nutritional status by maintaining diet, choosing the right and balanced foods, as well as increasing physical activities.
\end{abstract}

Keywords adolescent girls, dietary intake, IGF-1, nutritional status

\author{
Corresponding author: \\ Maretha Primariayu \\ Department of Nutrition Medical Faculty Universitas \\ Indonesia \\ Email address : dr.maretha@gmail.com
}

\section{Introduction}

Adolescence is a transition period when a child grows and develops into adult. There is a growth spurt in adolescent girls beginning on average at 910 years old. ${ }^{1}$ During growth spurt, these will occur: fast and intense increases in height, changes in body composition which causes weight gain, reproductive organ and secondary sexual characteristic development, and changes in the circulatory and respiratory system. ${ }^{2}$ Dramatically changes in the body of adolescent girls are the 
decrease in lean body mass and the increase in body fat. The body fat of girls increases by twofold before the end of puberty. ${ }^{2-4}$ The end of puberty for girls is marked by menarche, and the average age of menarche in Indonesia are 13 years old. ${ }^{5}$

Adolescent growth is influenced by endogenous factors such as genetic and hormonal or endocrine body as well as exogenous factors such as nutrition, physical activity, and environment. When these factors are disturbed, it could affect the adolescent's health, reflected in the nutritional status as measured by body mass index (BMI). Excess needs of energy intake in adolescent girls take a result in overweight and obesity, which could continue to adults. In obesity, the risk of insulin resistance increases and that can develop into diabetes or cardiovascular disease, and the risk of cancer would also increase. ${ }^{6-7}$

Insulin-like growth factor-1 (IGF-1) or somatomedin is the hormone which its synthesis is stimulated by growth hormone (GH). IGF-1 is the mediator of anabolic and mitogenic effects of growth hormone in supporting adolescent growth. ${ }^{8-9}$ Its levels will rise when growth spurt occurs and begin to decline at the end of puberty. ${ }^{10}$ Several studies showed that high IGF-1 levels in adults related to an increasing risk of several cancers, such as breast, colon, and prostate cancer. ${ }^{11}$ Metaanalysis study in breast cancer showed that higher IGF-1 level related with higher risk of premenopausal breast cancer. ${ }^{12}$ The level of IGF-1 is affected by several factors associated with lifestyle such as diet intake, anthropometry, and physical activity. ${ }^{13-15}$ In Indonesia, there is no data on IGF-1 levels in adolescent girls aged 13-15 . Therefore, this study was conducted to investigate the relationship between IGF-1 and nutritional status in adolescent girls as a prevention of the increasing risk of cancer when the teenagers become adults.

\section{Methods:}

\section{Study Design}

Participants in this cross-sectional study were adolescent girls from previous study titled "Determinant Factor Levels of Estradiol, IGF-1, and Early Menarche in Adolescent Girls Aged 1315 in Jakarta: Nutritional Epidemiology Study Related to Breast Cancer Risk Factors." In that previous study, the subjects had been recruited from January 2014 to January 2015. In this study, we used secondary data (such as dietary intake, anthropometry, and physical activities status) and primary data from the previous study stored blood serum. The eligible criteria were: subjects had no chronic illnesses, their parents signed the informed consent of prior research, subjects already had menarche and were not in steroid medication.

\section{Study Design}

The study was done in the selected eight Junior High Schools representing the five municipalities in Jakarta. This study started after obtaining permission from Medical Ethics Committee, Faculty of Medicine University of Indonesia

\section{Data Collection}

The dietary intakes (total of energy, carbohydrate, protein, and fat) were collected using semiquantitative food frequency questionnaire (FFQ) by experienced nutritionists. Dietary intake data were then analyzed using Nutrisurvey 2007. The total of energy and macronutrient intake were categorized as minimal $(<70 \%)$, low (70-99.9\%), normal (100$129.9 \%)$, and high $(\geq 130 \%)$, based on the Indonesian recommended daily allowance (RDA). Category of macronutrient intake also was categorized based on proportion of total macronutrient to energy. Height and weight were measured in accordance to the standard protocol by trained personnel. The results of measurements of weight and height were then used to calculate body mass index (BMI) using the formula weight (in $\mathrm{kg}$ ) divided by height (in meters) squared. BMI values were adjusted to BMI-for-age CDC 2000 chart for girl aged 2-20 using Children's BMI Tool for School to get BMI-for-age percentile. The subjects' aged 13-14 completed Physical Activities Questionnaire-Children (PAQ-C) and the subjects' physical activity level (PAL). IGF-1 levels were measured from the stored blood serum by colorimetric method in Dharmais Cancer Hospital laboratory, Jakarta. 
All data were analyzed using Statistical Package for Social Science (SPSS) version 20.0. Normality of data was analyzed using Kolmogorov Smirnov test. Normally distributed data were presented in mean \pm SD while not-normally distributed data were presented in median (minimum-maximum). The correlation between percentile values and diet intake with IGF-1 values was analyzed using Pearson or Spearman rank test. The difference of IGF-1 values between groups of nutritional status and dietary intake (based on proportion to energy) were analyzed using unpaired t-test or one-way
ANOVA. The $p<0.05$ was considered as statistical significance.

\section{Results}

The analyses were based on 178 adolescent girls with complete data on IGF-1 values. The characteristic data including anthropometric (weight, height, and BMI-for-age percentile), nutritional status, dietary intake, physical activity, and serum IGF-1 is presented in Table 1.

Table 1 Characteristic of subjects based on anthropometric, nutritional Status, dietary intake, and physical activity $(\mathrm{n}=178)$

\begin{tabular}{|c|c|c|}
\hline Characteristic & n (\%) & Mean \pm SD/median (min-max) \\
\hline Energy, kcal & & $1579.5(702.9-2962.8)$ \\
\hline \multicolumn{3}{|l|}{ Adequacy of energy intake } \\
\hline Minimal $(<70 \%$ RDA $)$ & $70(39.3)$ & \\
\hline Low (70-99.9\% RDA) & $81(45.5)$ & \\
\hline Moderate (100-129.9\% RDA) & $23(12.9)$ & \\
\hline High $(\geq 130 \%$ RDA $)$ & $4(2.2)$ & \\
\hline Total carbohydrate, g/day & & $211.8(74.3-432.9)$ \\
\hline \multicolumn{3}{|l|}{ Adequacy of carbohydrate intake } \\
\hline Minimal (<70\% RDA) & $77(43.3)$ & \\
\hline Low (70-99.9\% RDA) & $69(38.8)$ & \\
\hline Moderate $(100-129.9 \%$ RDA $)$ & $26(14.6)$ & \\
\hline High $(\geq 130 \%$ RDA $)$ & $6(3.4)$ & \\
\hline Total carbohydrate, $\%$ of energy & & $54.9 \pm 6.8$ \\
\hline \multicolumn{3}{|c|}{ Proportion of total carbohydrate to energy } \\
\hline \multicolumn{3}{|c|}{ Low $(<50 \%$ energy) } \\
\hline Moderate (50-60\% energy) & 39 (21.9) & \\
\hline \multirow[t]{2}{*}{ High ( $>60 \%$ energy) } & $96(53.9)$ & \\
\hline & $43(24.2)$ & \\
\hline Total protein, $g$ /day & & $45.5(13.8-128.3)$ \\
\hline \multicolumn{3}{|l|}{ Adequacy of protein intake } \\
\hline Minimal (<70\% RDA) & $100(56.2)$ & \\
\hline Low (70-99.9\% RDA) & $55(30.9)$ & \\
\hline Moderate (100-129.9\% RDA) & $14(7.9)$ & \\
\hline High $(\geq 130 \%$ RDA $)$ & $9(5.1)$ & \\
\hline Total protein, $\%$ of energy & & $11.8(7.1-37.5)$ \\
\hline \multicolumn{3}{|l|}{ Proportion of total protein to energy } \\
\hline Low $(<10 \%$ energy) & $31(17.4)$ & \\
\hline Moderate ( $10-20 \%$ energy) & $146(82.0)$ & \\
\hline High $(>20 \%$ energy) & $1(0.6)$ & \\
\hline Total fat, g/day & & $57.1(14-120.8)$ \\
\hline \multicolumn{3}{|l|}{ Adequacy of fat intake } \\
\hline Minimal (<70\% RDA) & $57(32)$ & \\
\hline Low (70-99.9\% RDA) & $73(41)$ & \\
\hline Moderate (100-129.9\% RDA) & $40(22.5)$ & \\
\hline High $(\geq 130 \%$ RDA $)$ & $8(4.5)$ & \\
\hline
\end{tabular}


Table 1 Characteristic of subjects based on anthropometric, nutritional Status, dietary intake, and physical activity $(\mathrm{n}=178)$ (Continued)

\begin{tabular}{lcc}
\hline Characteristic & n (\%) & Mean \pm SD/median (min-max) \\
\hline Total fat, \% energy & & $32.7 \pm 6.7$ \\
Proportion of total fat to energy & $37(3.9)$ & \\
Low (<20\% energy) & $47(26.4)$ & \\
Moderate (20-30\% energy) & $124(69.7)$ & \\
High ( $>30 \%$ energy) & & $45.9(31.0-80.2)$ \\
Weight, kg & & $152.6 \pm 6.2$ \\
Height, cm & & $58.5(0-98.6)$ \\
BMI-for-age percentile & $6(3.4)$ & \\
Nutritional status & $133(74.7)$ & \\
Underweight & $28(15.7)$ & \\
Normal & $11(6.2)$ & \\
Overweight & & \\
Obese & $165(92.7)$ & \\
Physical activities score & $13(7.3)$ & \\
Physical activities & & \\
Low & & \\
Moderate & & \\
IGF-1, ng/mL & & \\
&
\end{tabular}

Among these subjects, $84.8 \%$ had energy intake less than the RDA for adolescent girls aged 13-15. While $53.9 \%$ of the subjects had moderate proportion of carbohydrates intake to total energy, $82 \%$ of the subjects had moderate proportion of protein intake to total energy, and $69.7 \%$ of the subjects had high proportion of fat intake to total energy. There were only 6 subjects $(3.4 \%) 2$. underweight, and on the other hand 39 subjects $(21.9 \%)$ were overweight/obese. Almost all subjects had low physical activity level, i.e. 165 subjects $(92.7 \%)$, while the remaining 13 subjects $(7.3 \%)$ had moderate physical activities.

The correlations between IGF-1 with nutritional status and macronutrient intake are shown in Table

Table 2 Correlations between IGF-1 levels and BMI-for-age percentile and dietary intake ( $\mathrm{n}=178)$

\begin{tabular}{lcc}
\hline \multirow{2}{*}{ Variable } & \multicolumn{2}{c}{ IGF-1 Levels (ng/mL) } \\
\cline { 2 - 3 } & $\mathrm{p}$ & $\mathrm{r}$ \\
\hline BMI-for-age percentile & $0.754^{\ddagger}$ & -0.024 \\
Dietary intake & & \\
Energy, kcal & $0.758^{\ddagger}$ & 0.023 \\
Carbohydrate, \% of energy & $\mathbf{0 . 0 4 1}$ & $\mathbf{0 . 1 5 3}$ \\
Carbohydrate, g/day & $0.242^{\ddagger}$ & 0.088 \\
Protein, \% of energy & $0.237^{\ddagger}$ & -0.089 \\
Protein, g/day & $0.697^{\ddagger}$ & -0.029 \\
Fat, \% of energy & $\mathbf{0 . 0 4 2}$ & $\mathbf{- 0 . 1 5 2}$ \\
Fat, g/day & $0.229^{\ddagger}$ & -0.091 \\
\hline
\end{tabular}

* Pearson rank test $;{ }^{\ddagger}$ Spearman rank test 
There is no correlation between BMI-forage percentile and IGF-1. Of the diet variables, carbohydrate is associated to IGF-1 ( $p=0.041$, $\mathrm{r}=0.153)$, whereas fat is inversely associated to IGF-1 $(\mathrm{p}=0.042, \mathrm{r}=-0.152)$. We observed that there was no statistically significant difference in IGF-1 between nutritional status and diet intake groups. However, there was a trend that IGF-1 would increase in overweight group and decrease in obese groups (Figure 1).

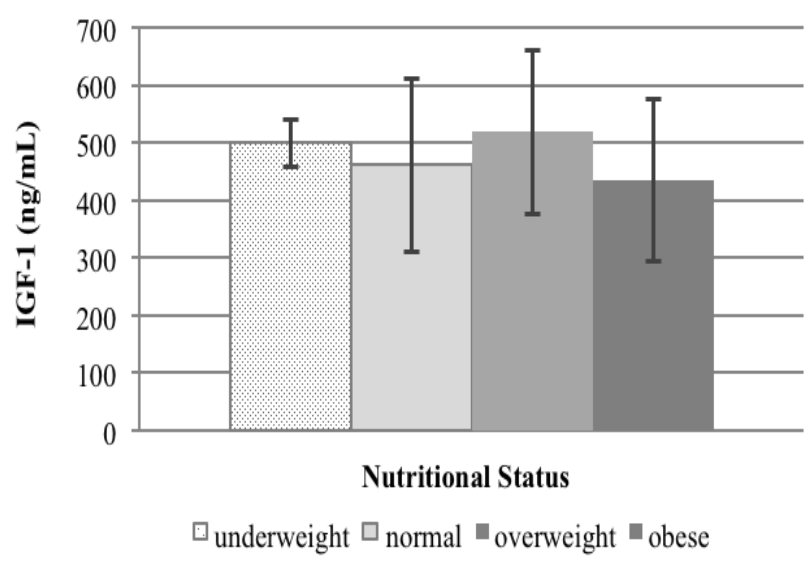

Figure 1 IGF-1 Difference between nutritional status groups

Also, there were smooth trends towards higher IGF-1 levels with increasing carbohydrate intakes and lower IGF-1 with increasing fat intake (Figure 2).
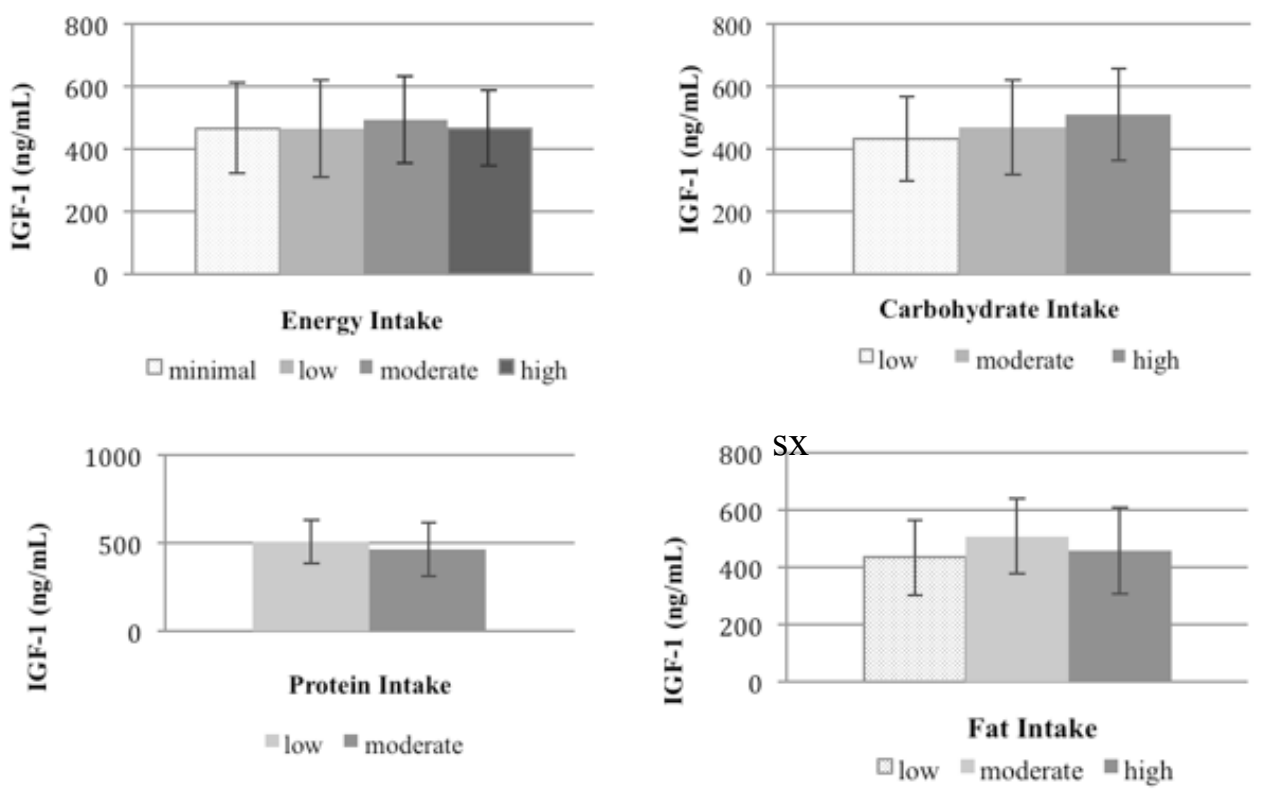

Figure 2 IGF-1 Difference between dietary intake group $(\mathrm{n}=178)$
This research was the first research conducted in Indonesia that measured the levels of IGF-1 in young girls accompanied by other comprehensive factors such as diet intake, anthropometry, and physical activity. The advantages of this study include the large number of subjects - nearly 200, the research conduct in eight schools among five areas in Jakarta, and the random selection. Sample collection was also carried out at the same time, i.e. in the morning, to prevent the diurnal variation of IGF-1 examination. ${ }^{16}$ Subjects were also carried out on fairly strict inclusion criteria to minimize other variations of health conditions that could affected the subjects. Therefore, the results of this study could be generalized to the population of adolescent girls aged 13-15 in major cities in Indonesia. Meanwhile, the weakness of this study is it used cross-sectional design that could be threatening by the possibility of the recall bias when taking dietary intake and physical activity data.

We found that almost all of the subjects had low physical activity level. The sedentary lifestyle may become the risk factors for non-communicable diseases (NCDs) that starting from childhood and adolescence. 
In spite of the sedentary lifestyle, unhealthy eating habits can be the cause of some degenerative diseases such as cardiovascular disease, metabolic syndrome and cancer. Furthermore, there is evidence that $90-95 \%$ of cancer is influenced by lifestyle factors and the environment. Focusing for cancer, especially breast cancer for the adolescent girls, it can be prevented with lifestyle modifications such as a good diet, maintaining a normal body weight, and increasing physical activities. ${ }^{17}$ Thus, it is very important the teen years become the focus of attention of the government to initiate programs in the prevention of degenerative diseases, especially cancer in the future.

This study examined the relationship between IGF-1 and nutritional status and dietary intake in adolescent girls aged 13-15. We found that there was no relationship between IGF-1 and BMI-for-age percentile. This study is consistent with the study of 243 girls in grade 6 and 7, in which there is no relationship between the levels of IGF-1 with the body composition such as body mass index, thickness of skin folds, waist/hip, height, and weight. ${ }^{18}$ Lukanova et al. ${ }^{14}$ reported there was no significant difference in the levels of IGF-1 in each group based on BMI in 391 adult women. However, the levels of IGF-1 in each group described the nonlinear relationship, which means the levels of IGF-1 will reach the highest level at a certain IMT, and then it will decrease. After grouping based on the nutritional status according to BMI-for-age, there was no statistically significant difference in IGF-1 between nutritional status groups. However, the pattern of mean levels of IGF-1 in each group tended not to be linear. IGF-1 levels increased from normal to overweight, then decreased in obese.

The nonlinear relationship between IGF-1 and BMI can be explained by the interaction of the two major determining factors of the synthesis and bioavailability of IGF-1, namely growth hormone $(\mathrm{GH})$ and insulin. $\mathrm{GH}$ is a major stimulus for the secretion of IGF-1 and the main carrier in the blood protein, IGFBP-3. In a condition like obesity, free fractions of IGF-1 increase because of the increased production by the liver and adipose tissue as well as the increase of insulin levels. The increase levels of insulin will also inhibit the synthesis of IGFBP-1 and IGFBP-2. Increased free fractions IGF-1 give negative feedback on GH. ${ }^{14,19,20}$ Decreased GH secretion in obesity also can be caused due to increased levels of free fatty acids in blood. A rise of free fatty acids in blood in obesity happens due to the enlarged fat cells which secrete free fatty acids in the blood more and the decrease clearance of free fatty acid. ${ }^{21,22}$ The decrease of GH secretion causes a decrease in total levels of IGF-1.

Excess body weight is estimated to be the cause of $20 \%$ of all cancer cases. In the last 25 years, the data showed that obesity is the cause of $20 \%$ of cancer deaths in women. A retrospective study showed an association between elevated BMI and the incidence of breast cancer in the premenopausal woman. ${ }^{23}$ On the other hand, a systematic review and meta-regression analysis of case-control studies which included 3,609 cases and 7,137 controls has demonstrated that high concentrations of IGF-I were associated with an increased risk premenopausal breast cancer. ${ }^{24}$ With the results from this study that IGF-1 levels increase in overweight adolescent, it can be a caution for adolescent girls to maintain their weight and nutritional status to avoid from increasing premenopausal breast cancer risk.

In this study, we also found a positive correlation between the levels of IGF-1 with the proportion of carbohydrate intake $(p=0.004$, $\mathrm{r}=0.153)$ and an inversed correlation with fat intake $(p=0.04, r=-0.152)$. There was no correlation between the levels of IGF-1 with a proportion of total energy intake and protein intake. Cui et al. ${ }^{25}$ reported a positive association between the proportion of carbohydrate intake with high levels of IGF-1 and a negative association between the proportion of fat intake with high levels of IGF-1. With substitution of $5 \%$ of the energy from carbohydrates for the equivalent amount of energy from fat or protein, IGF-1 levels increased by $2 \%$. When substituting $1 \%$ of the energy from fat for the equivalent amount of energy - a $1 \%$ increase in the proportion of fat to total energy, IGF-1 levels decreased by $2.8 \%$.

Changes in carbohydrate intake will provide an indirect effect on IGF-1 levels through changes in insulin secretion. The synthesis of IGF-1 in the liver is also regulated by insulin. Studies in animals showed that by blocking the action of insulin in the 
liver, serum IGF-1 levels decreased. Increased intake of carbohydrates will increase the amount of insulin in the circulation. Increased insulin stimulates GH secretion and has effects on IGF-1 gene transcription so that the levels of IGF-1 will rise. ${ }^{26}$ Inversed association between IGF-1 and fat intake can be explained due to increased fat intake can rise free fatty acids levels in the blood. The increase in free fatty acids will result in inhibition $\mathrm{GH}$ secretion. ${ }^{22}$ Inhibited $\mathrm{GH}$ secretion causes decreased secretion of IGF-1.

Several studies suggest that higher concentrations of IGF-I are associated with a reduced risk of degenerative diseases like osteoporosis, diabetes, and possibly heart disease; otherwise, they are also associated with increased risk of cancers including breast, prostate, and colon cancer. Most of the IGFrelated cancers are associated with dietary patterns, so the role of diet in regulating the IGF system has attracted interest. ${ }^{11}$ Circulating concentrations of IGF-I can be affected by dietary intake through some potential mechanisms include the inhibition of hepatic synthesis or indirectly through effects on IGFBPs. ${ }^{22}$ Thissen et al. ${ }^{27}$ reported that energy and protein intakes appear to increase IGF levels. The result of the studies about the effect of dietary fat, fiber, or carbohydrates on the IGF axis are inconsistent. $^{28-30}$ IGF-1 was associated with carbohydrate intake and this positive association has been observed to be positively associated with the risk of developing breast cancer. ${ }^{31}$ In this study, IGF-I was inversely associated with total fat intake. Our finding is inconsistent with the few prior studies which reported positive or no associations between fat intake and IGF-I levels. ${ }^{29,32}$ Positive association between high fat diet and high levels of IGF-1 with the risk of developing certain cancers has been observed. However, the finding in this study is consistent with the positive association between both high fat intakes and low IGF-I concentrations and the risk of coronary heart disease.

The study concluded that there was no correlation between IGF-1 and nutritional status, but there was a tendency that higher IGF-1 levels found in overweight. There was a positive correlation between IGF-1 levels and carbohydrate intake, and an inversed correlation between IGF-1 levels and fat intake. We suggest that adolescent girls maintain their weight to achieve normal nutritional status and get macronutrient intake within the recommended range.

\section{Conflict of Interest}

The authors of this paper declare there is no conflict of interest regarding this research.

\section{Open Access}

This article is distributed under the terms of the Creative Commons Attribution 4.0 International License (http://creativecommons.org/licenses/by/4.0/), which permits unrestricted use, distribution, and reproduction in any medium, provided you give appropriate credit to the original author(s) and the source, provide a link to the Creative Commons license, and indicate if changes were made.

\section{Acknowledgement}

The authors thank all the subjects for participating in the study thoroughly. This study received funding from the Research and Public Services Council (DRPM) Universitas Indonesia.

\section{References}

1. Soetjiningsih . Pertumbuhan somatik pada remaja. [Somatic growth in Adolescent]. In: Soetjiningsih. Tumbuh kembang remaja dan permasalahannya. [Growth and Development in Adeolescent and its Problems. Jakarta: Sagung Seto; 2004.

2. Batubara JRL. Adolescent development (perkembangan remaja). Sari Pediatri 2010;12:21-9.

3. Rogol AD, Clark PA, Roemmich JN. Growth and pubertal development in children and adolescents: effects of diet and physical activities. Am J Clin Nutr 2000;72(suppl):521.

4. Stang J. Adolescent nutrition. In: Brown JE, editor. Nutrition through life cycle 4th ed. Belmont: Wadsworth; 2011.

5. Agency of Health Research and Development of Ministry of Health Republic Indonesia. National Basic Health 
Research 2010. Jakarta: Ministry of Health Republic Indonesia; 2010.

6. Biro FM, Wien M. Childhood obesity and adult morbidities. Am J Clin Nutr 2010;91(suppl):1499.

7. Engeland A, Bjorge T, Tverdal A, Sogaard AJ. Obesity in adolescence and adulthood and the risk of adult mortality. Epidemiology 2004;15:79-85.

8. Sherwood L. Prinsip-prinsip endokrinologi: Kelenjar endokrin sentral. In: Yesdelita N, editor bahasa Indonesia. Fisiologi manusia dari sel ke sistem. $6^{\text {th }}$ edition. Jakarta: EGC; 2012.

9. Roith DL, Bondy C, Yakar S, Liu J, Butler A. The somatomedin hypothesis: 2001. Endocr Rev 2001;22:53-74.

10. Tiryakioglu O, Kadiolgu $\mathrm{P}, \mathrm{Nu} \mathrm{C}$, Hatemi $\mathrm{H}$. Age dependency of serum insulin-like growth factor (IGF)-1 in healthy Turkish adolescents and adults. Indian $\mathrm{J}$ Med Sci 2003;57:543-8.

11. Rogers IS, Gunnell D, Emmett PM, Glynn LR, Dunger DB, Holly JM, et al. Crosssectional associations of diet and insulinlike growth factor levels in 7- to 8-year-old children. Cancer Epidemiol Biomarkers Prev 2005;14:204-12.

12. Shi R, Yu H, McLarty J, Glass J. IGF-1 and breast cancer: a meta-analysis. Int $\mathrm{J}$ Cancer 2004;111:418-23.

13. R1 K, Lukanova A. Energy balance and cancer: the role of insulin and insulin-like growth factor-I. Proc Nutr Soc 2001;60:91106.

14. Lukanova A, Soderberg S, Stattin P, Palmqvist R, Lundin E, Biessy C, et al. Nonlinear relationship of insulin-like growth factor (IGF)-I and IGF-I/IGFbinding protein-3 ratio with indices of adiposity and plasma insulin concentrations (Sweden. Cancer Causes and Control 2002;13:509-16.

15. Kim TH, Chang JC, Kim H, Lee KH, Kong IK. Intense walking exercise affects serum IGF-1 and IGFBP3. J Lifestyle Med 2015;5:21-5.

16. J1 O, Johannsson G, Johansson JO, Lundberg PA, Lindstedt G, Bengtsson BA.
Diurnal variation in serum insulin-like growth factor (IGF)-I and IGF binding protein-3 concentrations during daily subcutaneous injections of recombinant human growth hormone in GH-deficient adults. Clin Endocrinol (Oxf 1997;46:63-8.

17. Anand P, Kunnumakara AB, Sundaram C, Harikumar KB, Tharakan A, Lai OS, et al. Cancer is a preventable disease that requires major lifestyle changes. Pharm Res 2008;25:2097-116.

18. Wilson DM, Killen JD, Hammer LD, Vosti C, Miner B, Hayward C, et al. Insulin-like growth factor-I as a reflection of body composition, nutrition, and puberty in sixth and seventh grade girls. J Clin Endocrinol Metab 1991;73:907-912.

19. Gram IT, Norat T, Rinaldi S, Dossus L, Lukanova A, Tehard B, et al. Body mass index, waist circumference and waist-hip ratio and serum levels of IGF-I and IGFBP3 in European women. Int $J$ Obes 2006;30:1623-31.

20. Faupel-Badger JM, Berrigan D, BallardBarbash R, Potischman N. Anthropometric correlates of insulin-like growth factor 1 (IGF-1) and IGF binding protein-3 (IGFBP3) levels by race/ethnicity and gender. Ann Epidemiol 2009; 19:841-9.

21. Boden G. Obesity and free fatty acids (FFA. Endocrinol Metab Clin North Am 2008;37:1-12.

22. Butler AA, Roith DL. Control of growth by the somatropic axis: growth hormone and the insulin-Llike growth factors have related and independent roles. Annu Rev Physiol 2001;63:141-64.

23. Carter S. A description of BMI and the incidence of breast cancer in the premenopausal woman. Electronic Thesis or Dissertation. Walsh University, 2015. https://etd.ohiolink.edu/

24. Renehan AG, Zwahlen $M$, Minder $C$, Dwyer, S.T. O', Shalet SM, Egger M. Insulin-like growth factor (IGF)-I, IGF binding protein-3, and cancer risk: systematic review and meta-regression analysis. The Lancet 2004;363:1346-53. 
25. Cui X, Willet WC, Hankinson SE. Dietary Fat, Fiber, and Carbohydrate Intake and Endogenous Hormone Levels in Premenopausal Women. Horm Cancer 2010;1:265-76.

26. Kerver JM, Gardiner JC, Dorgan JF, Rosen CJ, Velie EM. Dietary predictors of the insulin-like growth factor system in adolescent females: results from the Dietary Intervention Study in Children (DISC. Am J Clin Nutr 2010;91:643-50.

27. Thissen JP, Ketelslegers JM, Underwood LE. Nutritional regulation of the insulin-like growth factors. Endocr Rev 1994;15:80101.

28. Holmes MD, Pollak MN, Willett WC, Hankinson SE. Dietary correlates of plasma insulin-like growth factor I and insulin-like growth factor binding protein 3 concentrations. Cancer Epidemiol Biomarkers Prev 2002;11:852-61.

29. Kaklamani VG, Linos A, Kaklamani E, Markaki I, Koumantaki Y, Mantzoros CS. Dietary fat and carbohydrates are independently associated with circulating insulin-like growth factor 1 and insulin-like growth factor-binding protein 3 concentrations in healthy adults. Journal of Clinical Oncology 1999;17(10):3291-8.

30. Nagata C, Shimizu H, Takami R, Hayashi M, Takeda N, Yasuda K. Dietary soy and fats in relation to serum insulin-like growth factor-1 and insulin-like growth factorbinding protein-3 levels in premenopausal Japanese women. Nutr Cancer 2003;45:185-9.

31. Cho E, Spiegelman D, Hunter DJ, Chen WY, Colditz GA, Willet WC. Premenopausal Dietary Carbohydrate, Glycemic Index, Glycemic Load, and Fiber in Relation to Risk of Breast Cancer. Cancer Epidemiol Biomarkers Prev 2003;12:1153-8.

32. Norat T, Dossus L, Rinaldi S, Overvad K, Gronbaek H, Tjonneland A, et al. Diet, serum insulin-like growth factor-I and IGFbinding protein-3 in European women. Eur J Clin Nutr 2007;6:91-98. 